\title{
Mechanical Properties and Durability of High-Performance Concretes Blended with Circulating Fluidized Bed Combustion Ash and Slag as Replacement for Ordinary Portland Cement
}

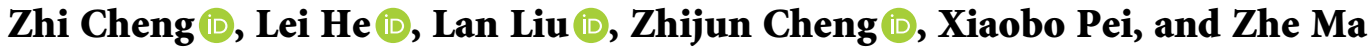 \\ School of Science, North University of China, Taiyuan 030051, China \\ Correspondence should be addressed to Lan Liu; yunvlan@163.com
}

Received 24 May 2020; Revised 18 July 2020; Accepted 18 August 2020; Published 29 September 2020

Guest Editor: Vojtěch Václavík

Copyright @ 2020 Zhi Cheng et al. This is an open access article distributed under the Creative Commons Attribution License, which permits unrestricted use, distribution, and reproduction in any medium, provided the original work is properly cited.

\begin{abstract}
This study investigates the mechanical properties and durability of three families of high-performance concrete (HPC), in which the first was blended with fly ash, the second with circulating fluidized bed combustion (CFBC) ash, and the third with CFBC slag. In addition to each of the three mineral additives, silica fume and a superplasticizer were also incorporated into the HPC. Hence, three families of HPC, containing $10 \%, 20 \%$, and $30 \%$ mineral admixtures and $9 \%$ silica fume of the binder mass, respectively, were produced. The microstructure and hydration products of the HPC families were examined by scanning electron microscopy (SEM) and X-ray diffraction (XRD) to explore the influence of fly ash, CFBC ash, and CFBC slag on the compressive strength and frost resistance of HPC. The experimental results show that the compressive strength of HPC could reach $60 \mathrm{MPa}$ at $28 \mathrm{~d}$ age. When the fly ash content was $30 \%$, the compressive strength of HPC was $70.2 \mathrm{MPa}$ at $28 \mathrm{~d}$ age; after the freeze-thaw cycle, the mass loss and strength loss of HPC were $0.63 \%$ and $8.9 \%$, respectively. When the CFBC ash content was $20 \%$, the compressive strength of HPC was $75 \mathrm{MPa}$ at $28 \mathrm{~d}$ age. After the freeze-thaw cycle, the mass loss and strength loss of HPC were $0.17 \%$ and $0.81 \%$, respectively.
\end{abstract}

\section{Introduction}

Coal-fired power generation in traditional thermal power plants results in the emission of a large amount of sulfur dioxide $\left(\mathrm{SO}_{2}\right)$, causing serious environmental pollution [1]. By using the circulating fluidized bed combustion (CFBC) technology, which has a higher combustion and desulfurization efficiency, $\mathrm{SO}_{2}$ emission can be greatly reduced. Therefore, this technology has been vigorously promoted in China [2-4]. In this technique, limestone is added as a desulfurizer to the CFBC boiler, so that the boiler discharges a greater amount of ash and slag compared with the pulverized coal boiler [5-7]. Currently, more than 50 million tons of CFBC ash and slag are discharged annually in China [8-10]. As studies on the CFBC ash and CFBC slag are few, CFBC ash and CFBC slag are still not used on a large scale [11-14]. Ash and slag pollute the environment while occupying the land; therefore, governments and power plants have sought effective methods to dispose them [15-18], especially since the environmental protection tax law was enacted on January 1, 2018.

With the development in the concrete industry, highperformance concrete (HPC), a material with very low porosity, has received great attention due to its excellent mechanical properties and durability [19-21]. To improve the properties of HPC, mineral admixtures with high pozzolanic reactivity, such as silica fume and ground granulated slags, are usually added [22-24]. Mineral admixtures have gradually become a research focus, and fly ash has become one of the main mineral admixtures [25-27].

Fly ash, which is discharged from pulverized coal boilers, has been intensively and widely researched. With the same as fly ash, CFBC ash and CFBC slag also contain some amount of $\mathrm{SiO}_{2}$ and $\mathrm{AlO}_{3}$. So, the CFBC ash and CFBC slag have pozzolanic activity too [28]. Abed and Nemes [29] investigated the influence of fly ash on self-compacting HPC and found that the 
concrete containing $15 \%$ fly ash had better durability performance. Xu et al. [30] researched the effect of fineness and the CFBC ash composition on compressive strength, setting time, and consistency of basic magnesium sulfate cement and observed that with an increase in the fineness of CFBC ash, the consistency of the cement paste increased, the setting time shortened, and the compressive strength slightly improved; this indicates that fine CFBC ash is a good raw material for preparing basic magnesium sulfate cement. Nguyen et al. [31] studied the engineering performance and durability of concrete modified with CFBC ash so that it contained a high volume of low-calcium fly ash. The experiment results showed that the CFBC ash addition did not influence the stability and passing and filling abilities of concrete. However, CFBC ash could significantly improve the compressive strength, bonding property, and durability of concrete.

The CFBC ash and CFBC slag contain some amount of f- $\mathrm{CaO}$ and $\mathrm{II}-\mathrm{CaSO}_{4}$. Excessive $\mathrm{f}-\mathrm{CaO}$ and II-CaSO 4 will cause concrete damage due to volume expansion in the later stage [32-34]. To eliminate this adverse effect, CFBC ash and CFBC slag should be modified by physical or chemical methods. Studies have shown that physical grinding can decrease the volume expansion of the concrete while increasing the activity of the admixtures [35]. In this study, to prepare HPC, fly ash, CFBC ash, and ground CFBC slag were used as admixtures to replace cement. The influences of different admixtures on the mechanical properties and durability of HPC were also explored. The research results can provide a new basis and reference for the utilization of CFBC ash and slag and the preparation of HPC.

\section{Materials and Methods}

2.1. Materials. Grade PO 42.5 Portland cement (PC) from the Zhihai Cement Plant was used in this experiment. Its density was $3.100 \mathrm{~g} / \mathrm{cm}^{3}$, and its specific surface area was $357 \mathrm{~m}^{2} / \mathrm{kg}$. Its physical properties are presented in Table 1 .

Fly ash (II), which was raw ash from the Taiyuan second thermal power plant, was used in this work. Moreover, CFBC ash and CFBC slag were also used and were obtained from the Pingshuo Coal Gangue Power Plant of Shanxi Province, China. Ground CFBC slag was prepared by grinding the raw $\mathrm{CFBC}$ slag for $39 \mathrm{~min}$. The chemical compositions of cement, fly ash, CFBC ash, and CFBC slag are presented in Table 2. Silica fume was also used and was obtained from the Langtian Silica Fume Factory in Sichuan Province, China. The main parameters of the silica fume are listed in Table 3.

Figures 1 and 2 show the scanning electron microscopic (SEM) micrographs and X-ray diffraction (XRD) patterns of fly ash, CFBC ash, and ground CFBC slag, respectively. As can be seen from the SEM micrographs, the CFBC ash particles were irregular, the surface was coarse and porous, and agglomeration was obvious. The ground CFBC slag also featured irregular and coarse and porous lumps, but fly ash particles were regularly spherical, smooth, and dense. The $\mathrm{XRD}$ patterns show the presence of quartz, anhydrite, $\mathrm{f}-\mathrm{CaO}$, hematite, and calcite in the fly ash, CFBC ash, and CFBC slag. However, fly ash also contained mullite.
The fine aggregate was natural river sand $(S)$ with a fineness modulus of 2.8 and apparent density of $2.65 \mathrm{~g} / \mathrm{cm}^{3}$. The coarse aggregate was crushed limestone with a particle size of 5-20 mm and an apparent density of $2.79 \mathrm{~g} / \mathrm{cm}^{3}$.

Polycarboxylate superplasticizer, produced by the Taiyuan concrete superplasticizer factory, was used as the water-reducing admixture. The water reduction rate was $34 \%$.

2.2. Methods. In this study, a total of 9 groups of experiments were designed. Three concrete specimens were fabricated to test the compressive strength and frost resistance of each age. The values in Figures 3 and 4 are the average value of three concrete specimens. The mixture proportions are presented in Table 4 . The water-to-binder ratio (W/B) was 0.3. Fly ash, CFBC ash, and ground CFBC slag were used to replace cement, at each of the three dosages of $10 \%, 20 \%$, and $30 \%$. The amount of silica fume was $9 \%$ of the total binder materials. A water-reducing admixture was used to adjust the slump flow. The slump flow values of all the HPCs were controlled within $550-655 \mathrm{~mm}$, which belong to grade SF1.

In this study, the density was tested in accordance with GB/7208-2014 Cement Density Method. The chemical composition was referred to the chemical titration method in GB/T 176 Chemical Analysis Methods of Cement. The calculation method of activity index is carried out in accordance with GB/T 18046 Granulated Blast Furnace Slag Powder Used in Cement and Concrete. The specific surface area shall be determined in accordance with the GB/T 8074 Method for determination of the specific surface area of the cement Blaine method. The adsorption property of silica fume was characterized by the BET nitrogen adsorption method, and its specific surface area was obtained.

The working performance is carried out in accordance with JGJ/T283-2012 Technical Specification for Application of Self-compacting Concrete. According to the filling requirements of the self-compacting index performance, highperformance concrete is carried out with the performance level of $\mathrm{SF}_{1}$; that is, it meets the requirement of no reinforcement from the top or a concrete structure with less reinforcement. This test strictly controls the slump expansion range from 550 to $655 \mathrm{~mm}$.

In this study, the specimens were placed in a standard curing box with a temperature of $20 \pm 2{ }^{\circ} \mathrm{C}$ and a relative humidity of more than $95 \%$ for curing. After 24 hours, the molds were taken out and demolded. After demoulding, the specimens were placed in $20 \pm 3^{\circ} \mathrm{C}$ water for curing and taken out after the specified age for relevant tests.

The compressive strength tests were performed using a $3000 \mathrm{kN}$ universal compression machine in accordance with the GB/T 50081-2002 Standard Test Method for Mechanical Properties of Ordinary Concrete. In this study, $100 \times 100 \times 100 \mathrm{~mm}$ cubes were tested. The compressive strength of concrete was tested at $3 \mathrm{~d}, 7 \mathrm{~d}$, and $28 \mathrm{~d}$ ages, respectively.

The frost resistance property tests were formed using KDR-V9 concrete rapid freeze-thaw testing machine in 
TABLe 1: Physical properties of the portland cement.

\begin{tabular}{|c|c|c|c|c|c|c|c|c|}
\hline \multirow[t]{2}{*}{ Specific surface area $\left(\mathrm{m}^{2} / \mathrm{kg}\right)$} & \multicolumn{2}{|c|}{ Setting time $(\min )$} & \multicolumn{3}{|c|}{$\begin{array}{l}\text { Flexural strength } \\
(\mathrm{MPa})\end{array}$} & \multicolumn{3}{|c|}{$\begin{array}{l}\text { Compressive strength } \\
(\mathrm{MPa})\end{array}$} \\
\hline & Initial setting time & Final setting time & $3 \mathrm{~d}$ & $7 \mathrm{~d}$ & $28 \mathrm{~d}$ & $3 \mathrm{~d}$ & $7 \mathrm{~d}$ & $28 \mathrm{~d}$ \\
\hline 357 & 21 & 241 & 5.5 & 7 & 8.7 & 26.1 & 29.6 & 50.3 \\
\hline
\end{tabular}

TABLe 2: Chemical compositions of cement, fly ash, CFBC ash, and CFBC slag (wt. \%).

\begin{tabular}{lcccccccc}
\hline Sample & $\mathrm{SiO}_{2}$ & $\mathrm{Al}_{2} \mathrm{O}_{3}$ & $\mathrm{Fe}_{2} \mathrm{O}_{3}$ & $\mathrm{CaO}$ & $\mathrm{SO}_{3}$ & $\mathrm{MgO}$ & $\mathrm{K}_{2} \mathrm{O}$ & $\mathrm{LOI}(\%)$ \\
\hline Cement & 20.84 & 4.14 & 3.35 & 65.88 & 2.80 & 1.89 & 0.60 & - \\
Fly ash & 47.50 & 30.37 & 3.97 & 5.83 & 0.93 & 0.48 & 0.69 & 3.43 \\
CFBC ash & 37.78 & 32.76 & 5.42 & 10.19 & 4.35 & 1.93 & 0.98 & 6.09 \\
CFBC slag & 40.29 & 32.11 & 3.77 & 10.27 & 3.89 & 1.43 & 1.05 & 6.52 \\
\hline
\end{tabular}

TABLe 3: Main parameters of silica fume (wt. \%).

\begin{tabular}{lccccc}
\hline $\mathrm{SiO}_{2}$ & $\mathrm{Cl}^{-}$ & Water demand ratio & Specific surface $\left(\mathrm{m}^{2} / \mathrm{kg}\right)$ & Activity index & Total alkalinity \\
\hline 95.00 & 0.012 & 113 & 23700 & 122 & 0.23 \\
\hline
\end{tabular}

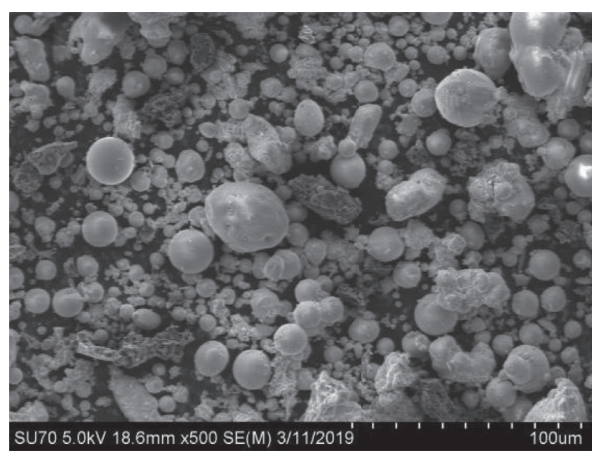

(a)

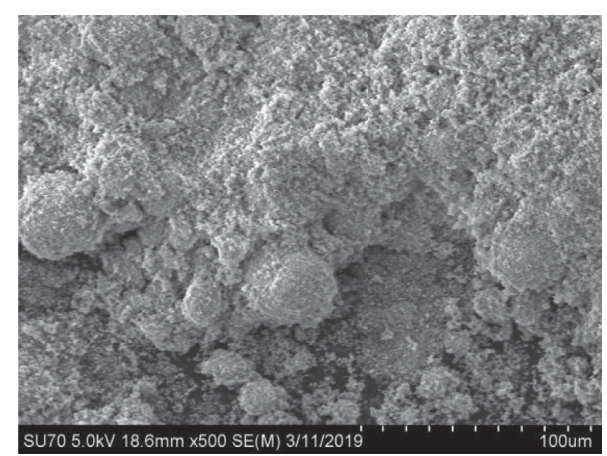

(b)

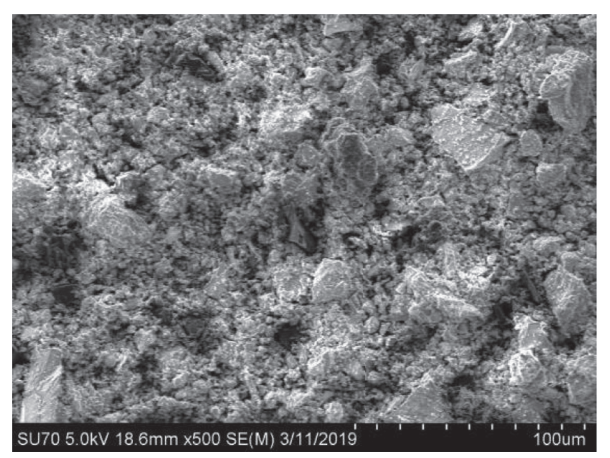

(c)

Figure 1: SEM micrographs of (a) fly ash, (b) CFBC ash, and (c) CFBC slag.

accordance with GB/T 50082-2009 Standard Test Methods for Long-Term Performance and Durability of Ordinary Concrete. In this study, $100 \times 100 \times 100 \mathrm{~mm}$ cubes were tested. In this test, 25 freeze-thaw cycles are used as a group. After each cycle is taken out of the instrument, its mass is weighed. Stop the test when the mass loss rate exceeds $5 \%$, the compressive strength loss rate exceeds $25 \%$, or 50 freezethaw cycles are reached.

The XRD patterns were detected using the D/max-RB XRD system (Japan Rigaku Corporation, Tokyo, Japan). The microstructures were detected using SEM (Hitachi S 4800 and SU-70; Hitachi, Ltd., Tokyo, Japan).

\section{Results and Discussion}

3.1. Mechanical Properties of HPC. The compressive strength of HPC specimens is illustrated in Figure 3. For all of the specimens, the compressive strength at $3 \mathrm{~d}$ ages reached $40 \mathrm{MPa}$, indicating early strength characteristics. The compressive strength of $\mathrm{S} 4-\mathrm{S} 8$ reached $80 \mathrm{MPa}$ at $90 \mathrm{~d}$ ages. 


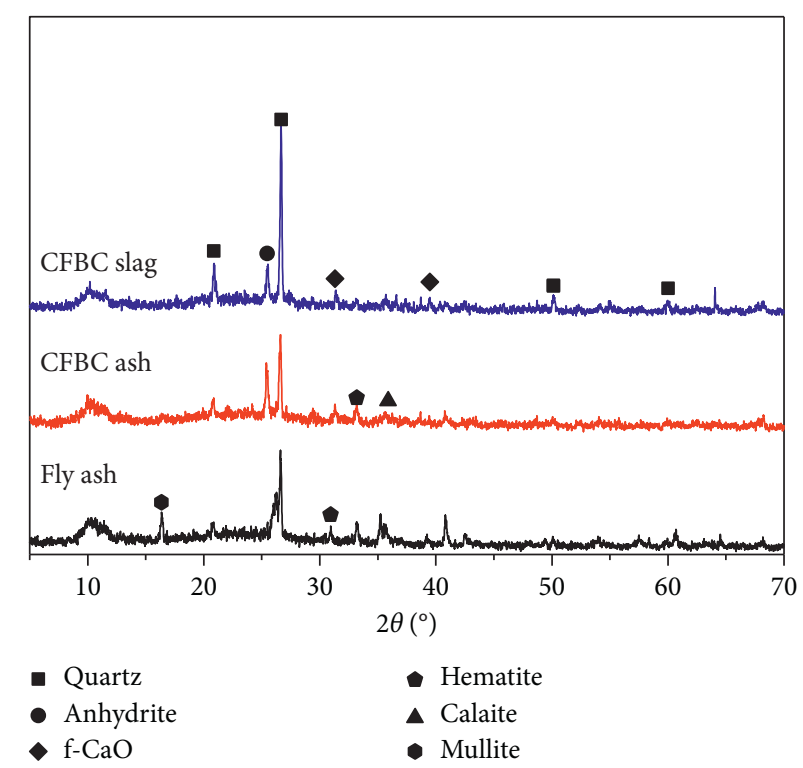

FIgURe 2: XRD patterns of fly ash, CFBC ash, and CFBC slag.
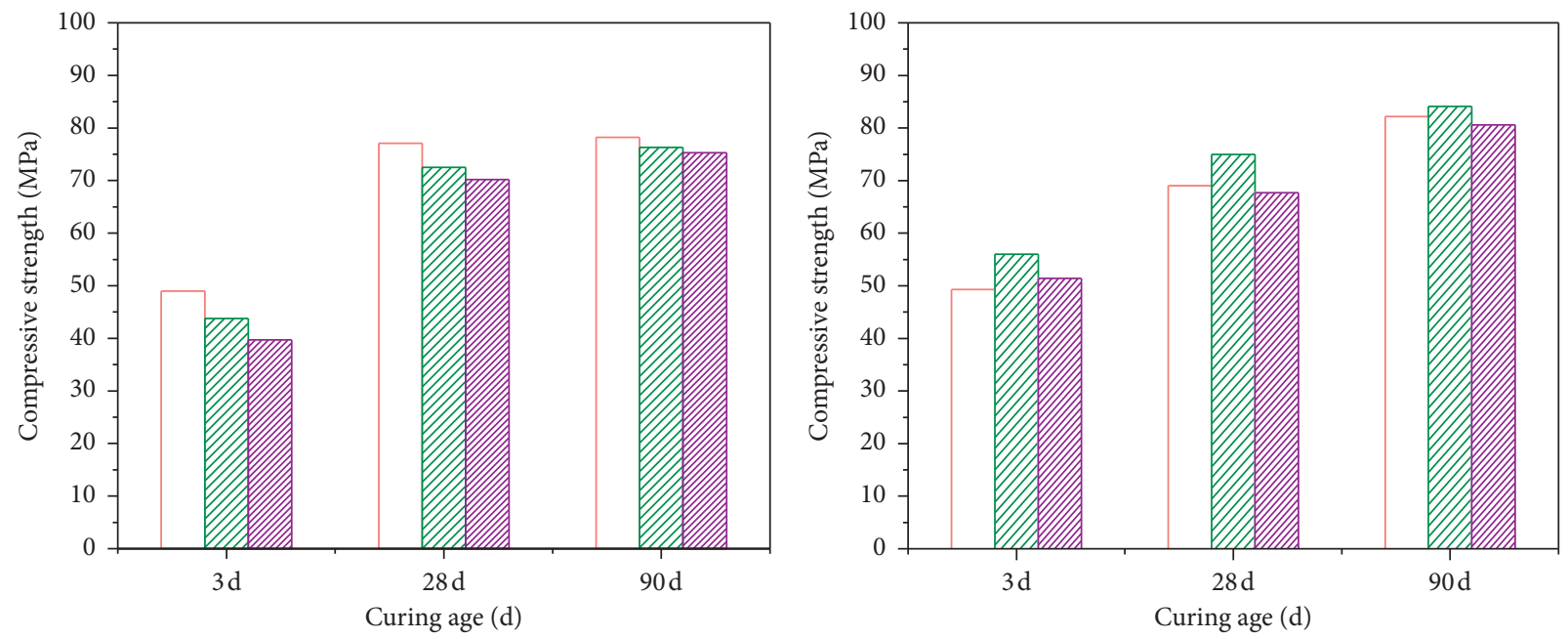

\begin{tabular}{ll}
\hline & $S 1$ \\
UIIIA & S2 \\
VIIIIA & S3
\end{tabular}

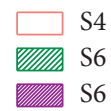

(a)

(b)

Figure 3: Continued. 


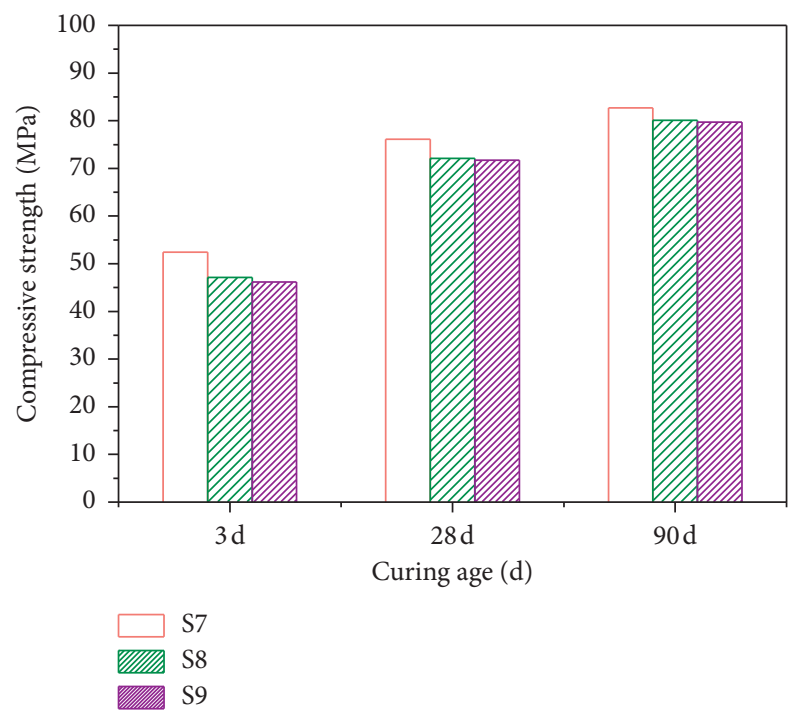

(c)

FIGURE 3: Compressive strength of HPC with different mineral admixtures. (a) Fly ash; (b) CFBC ash; (c) CFBC slag.

For ordinary concrete (without adding fly ash, CFBC ash, and CFBC slag), W/B is 0.3 , silica fume content is $9 \%$, and its $28 \mathrm{~d}$ ages compressive strength exceeds $70 \mathrm{MPa}$ [36]. When the $\mathrm{W} / \mathrm{B}$ is 0.3 and the silica fume content is $10 \%$, the compressive strength at $28 \mathrm{~d}$ ages exceeds $80 \mathrm{MPa}[37,38]$. Compared with ordinary concrete, the $28 \mathrm{~d}$ ages compressive strength of concrete mixed with fly ash, CFBC ash and CFBC slag is slightly lower. But the compressive strength of S1-S9 specimens at $28 \mathrm{~d}$ ages could reach $60 \mathrm{MPa}$, which belongs to high-strength concrete. As shown in Figure 3(a), with the increase in the amount of fly ash, the compressive strength of HPC decreased continuously. It can be seen from Figure 3(b) that with the increase of the CFBC ash amount, the compressive strength of HPC first increased and then decreased. According to Figure 3(c), with the increase of the amount of CFBC slag, the compressive strength of HPC decreased continuously. From Figure 3, the effect of mineral admixtures on the compressive strength of concrete is more obvious. The $D$-value between the maximum and minimum of the $3 \mathrm{~d}$ ages compressive strength of fly ash, CFBC ash, and CFBC slag is greater than $10 \%$. But in the later curing age, the effect on strength is not obvious.

It can be seen from Figure 4(a) that when the admixture amount was $10 \%$, the compressive strength of HPC with CFBC slag was higher than that of the other HPCs at $3 \mathrm{~d}$ and $90 \mathrm{~d}$ ages. Figure 4(b) shows that when the admixture amount was $20 \%$, the compressive strength of the HPC with CFBC ash was higher than that of the other HPC at all ages. According to Figure 4(c), when the amount was 30\%, the compressive strength of the HPC with CFBC ash was the highest at the $3 \mathrm{~d}$ and $90 \mathrm{~d}$ ages. And when the amount was $30 \%$, the compressive strength of the HPC with CFBC slag was the highest at the $28 \mathrm{~d}$ ages. These indicate that the medium-term strength developed slowly when the amount of CFBC ash was $30 \%$.
The XRD patterns of HPCs with different mineral admixtures are shown in Figure 5. As can be seen from the figure, the hydration products of HPC mainly included hydrated calcium silicate gel, gypsum, calcium hydroxide, and ettringite. Calcite appears in Figure 5 for two reasons: on the one hand, it comes from the coarse aggregate. On the other hand, it comes from the unreacted limestone residue in the CFBC ash and CFBC slag; that is, the limestone that is not completely thermally decomposed during the CFBC. It can be seen that as the age increases, the XRD peak intensity of $\mathrm{Ca}(\mathrm{OH})_{2}$ decreases, whereas the XRD peak intensity of gypsum increases. The main reaction of calcium hydroxide was to produce a C-S-H gel and react with gypsum to form ettringite, whereby C-S-H gel and ettringite are the main materials to form the strength of the cementitious system $[39,40]$. In addition, the ground CFBC slag is conducive to maximize the activities of various substances [41, 42]. As shown in Figure 6, large amounts of gypsum and C-S-H gel were found.

3.2. Frost Resistance of HPC. Figure 7 illustrates that as the amount of admixture increases, the compressive strength and mass loss rate of HPC first decreased and then increased. When the amount was $20 \%$, the strength and mass loss rate of HPC were the minimum, and the frost resistance was the highest. For the HPC with fly ash, fly ash particles can evenly fill internal pores at the early age to block water channels, and hydration products generated by the secondary hydration reaction in the later age can improve the pore structure while filling pores, thereby improving the frost resistance of HPC. However, when the fly ash amount is too high, the proportion of cement decreases, resulting in a large reduction in gel, ettringite, and so on, and therefore, the internal pores 


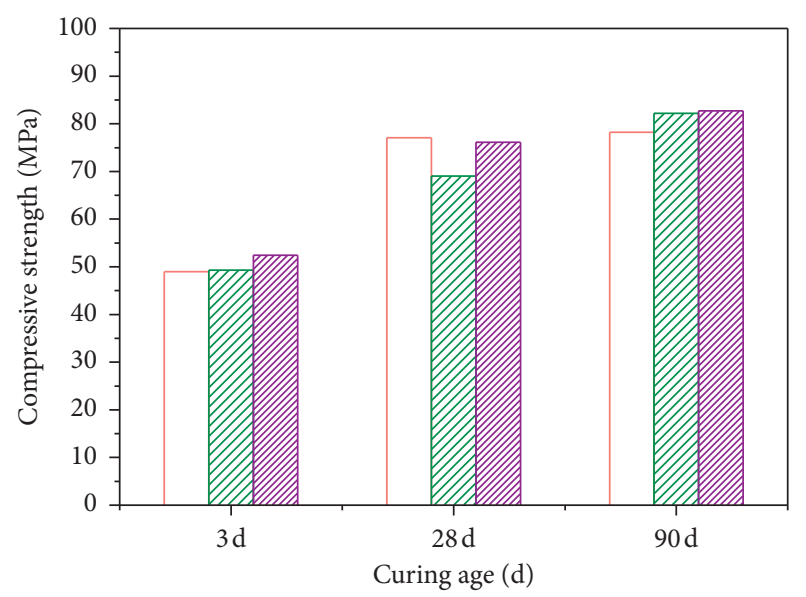

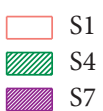

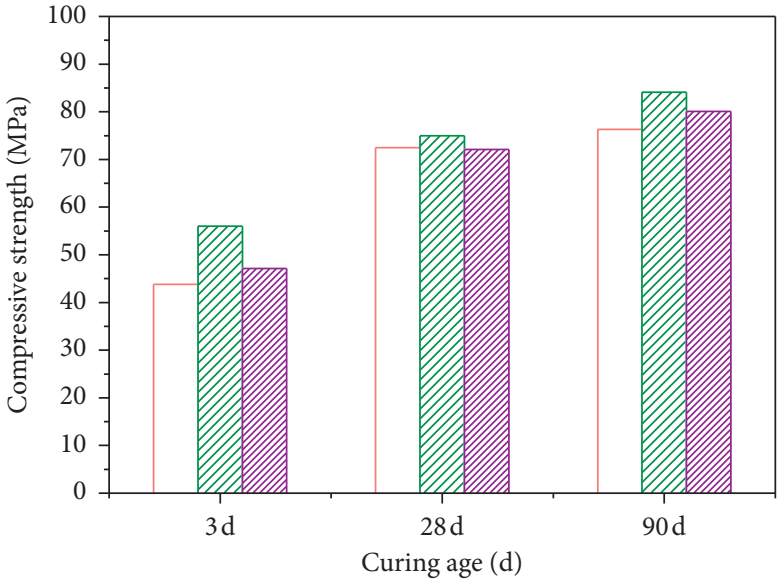

$\square$ S2

VIIIA S5

긴

(b)

(a)

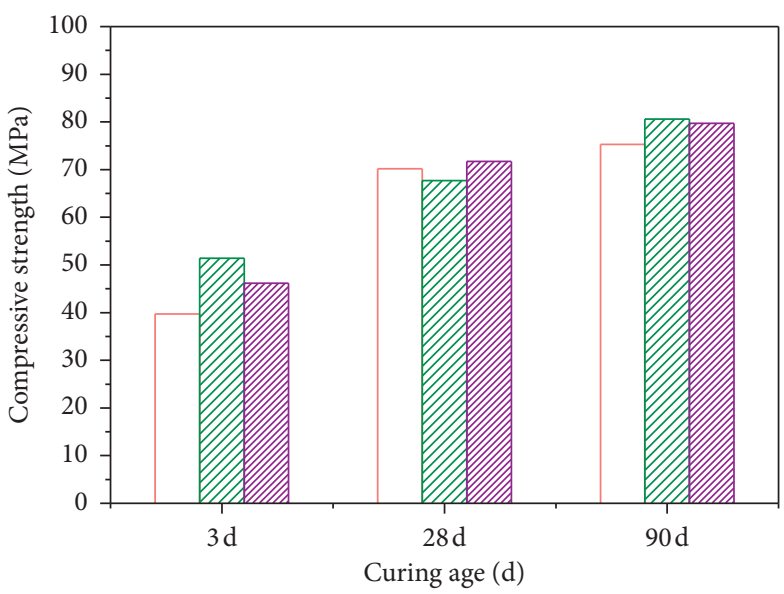

\begin{tabular}{lr}
\hline & S3 \\
WIIA & S6 \\
WIIIA S9 & S9
\end{tabular}

(c)

FIGURE 4: Compressive strength of HPC with different amounts of mineral admixtures. (a) $10 \%$; (b) $20 \%$; (c) $30 \%$.

TABle 4: Mixture proportions of HPC $\left(\mathrm{kg} / \mathrm{m}^{3}\right)$.

\begin{tabular}{lccccccccc}
\hline Mixture & W/B & Fine aggregate & Coarse aggregate & Fly ash & CFBC ash & CFBC slag & Silica fume & Cement & Water-reducing admixture \\
\hline S1 & 0.3 & 790 & 890 & 56 & - & - & 50.4 & 453.6 & 6.16 \\
S2 & 0.3 & 790 & 890 & 112 & - & - & 50.4 & 397.6 & 6.72 \\
S3 & 0.3 & 790 & 890 & 168 & - & - & 50.4 & 341.6 & 7.84 \\
S4 & 0.3 & 790 & 890 & - & 56 & - & 50.4 & 453.6 & 5.6 \\
S5 & 0.3 & 790 & 890 & - & 112 & - & 50.4 & 397.6 & 7.28 \\
S6 & 0.3 & 790 & 890 & - & 168 & - & 50.4 & 341.6 & 8.4 \\
S7 & 0.3 & 790 & 890 & - & - & 56 & 50.4 & 453.6 & 5.6 \\
S8 & 0.3 & 790 & 890 & - & - & 112 & 50.4 & 397.6 & 6.72 \\
S9 & 0.3 & 790 & 890 & - & - & 168 & 50.4 & 341.6 & 10.08 \\
\hline
\end{tabular}




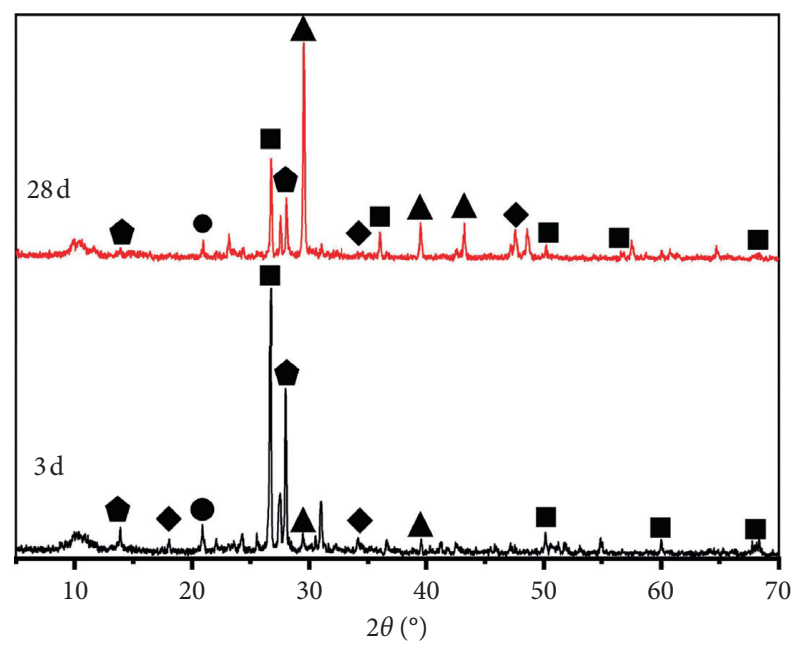

- Quartz

- Gypsum

- Portlandite

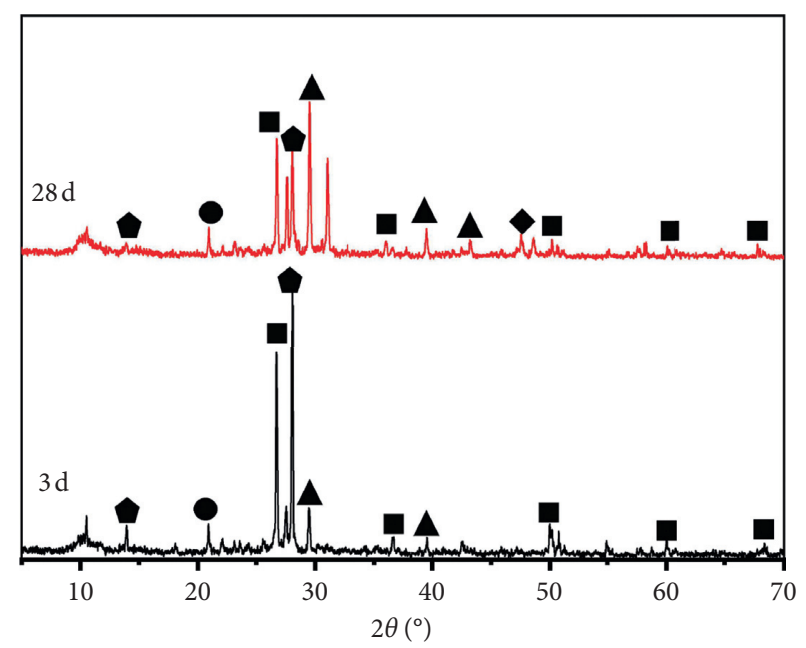

- Quartz

- Gypsum

- Portlandite

- Ettringite

A Calcite

(b)

(a)

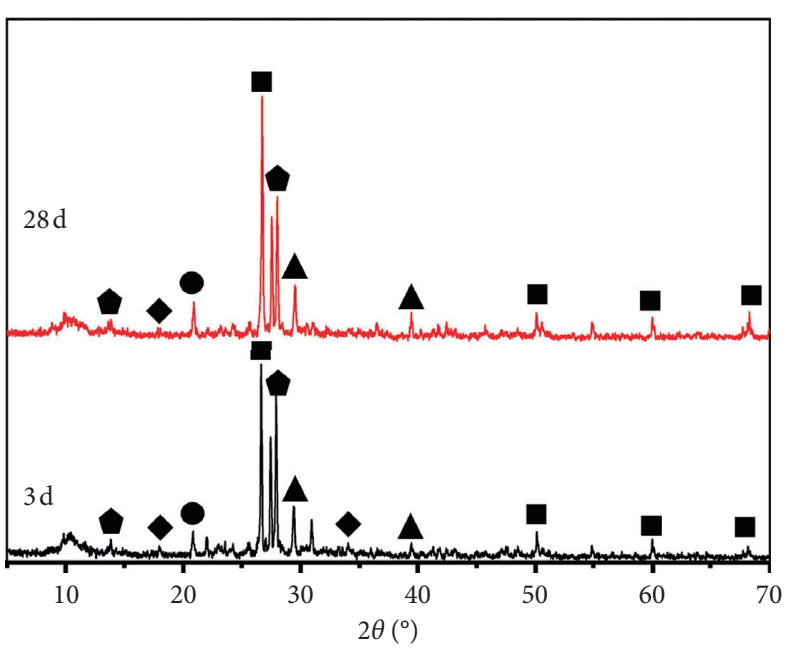

- Quartz

- Gypsum

- Portlandite
- Ettringite

A Calcite

(c)

FIgURE 5: XRD pattern of HPC with different mineral admixtures. (a) Fly ash; (b) CFBC ash; (c) CFBC slag.

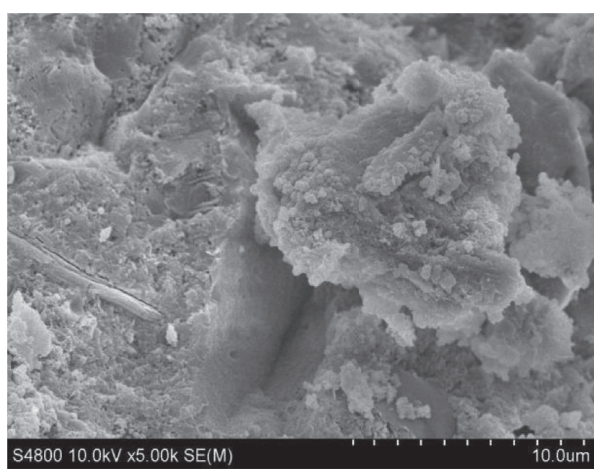

(a)

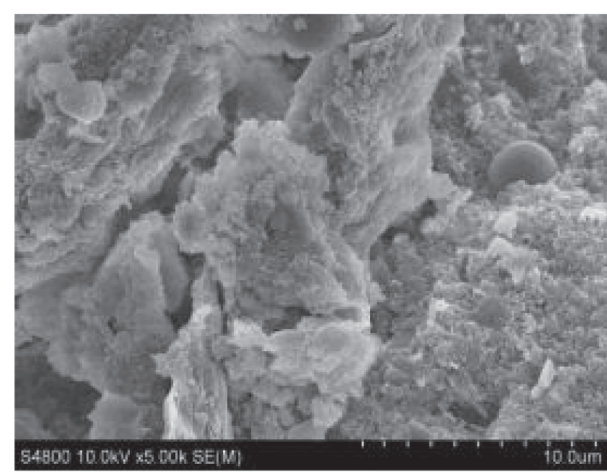

(b)

Figure 6: Continued. 


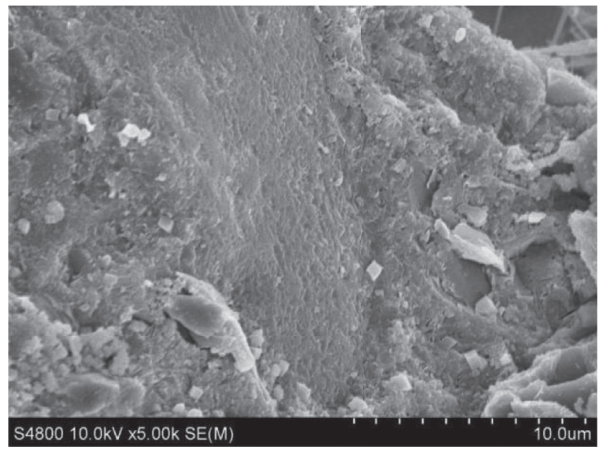

(c)

FIgURE 6: SEM of HPC with different mineral admixtures. (a) Fly ash; (b) CFBC ash; (c) CFBC slag.

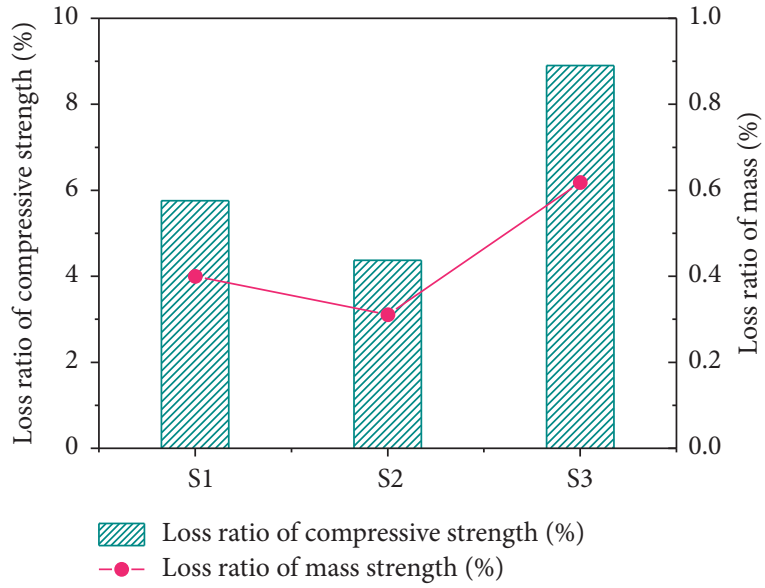

(a)

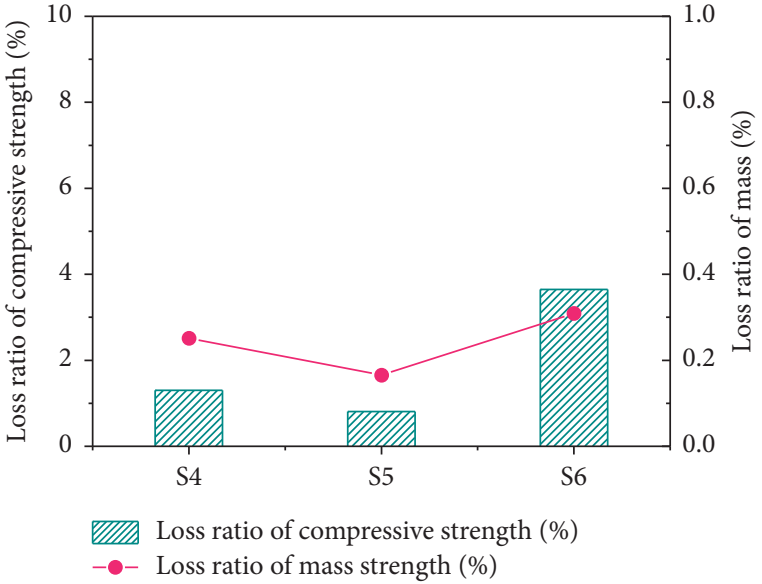

(b)

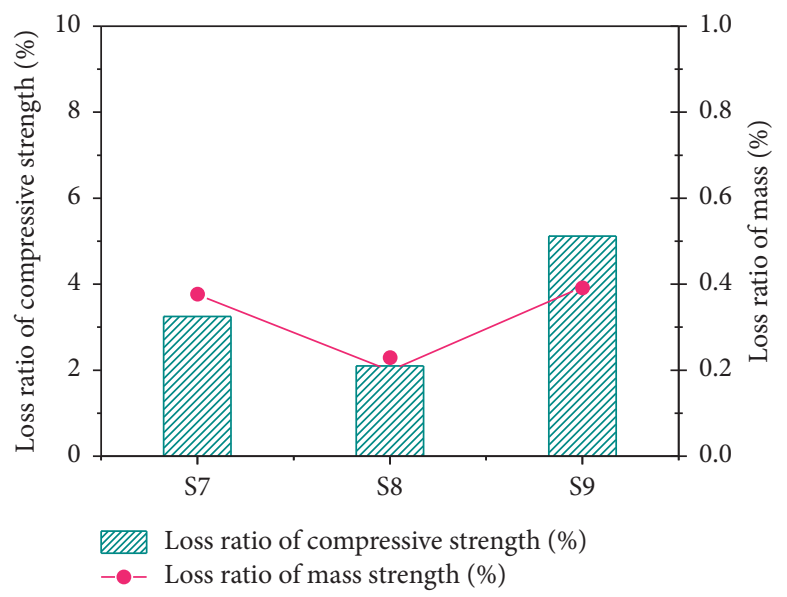

(c)

Figure 7: Compressive strength and mass loss rate of HPC with different mineral admixtures. (a) Fly ash; (b) CFBC ash; (c) CFBC slag.

cannot be filled. The amount of $\mathrm{Ca}(\mathrm{OH})_{2}$ produced is not enough to support the secondary hydration reaction of fly ash, resulting in a reduction in the strength and frost resistance of HPC [43].

The CFBC ash and CFBC slag all contain $\mathrm{f}-\mathrm{CaO}$ and II$\mathrm{CaSO}_{4}$, which can react to form hydration products and chemically react with other mineral components to form $\mathrm{C}-\mathrm{S}-\mathrm{H}$ gel and ettringite. And this will cause the strength of the concrete to increase rapidly and the expansion will develop inward [35], thus greatly improving the compactness of the HPC by blocking the interior water passages. Therefore, the frost resistance of the HPC improved. 


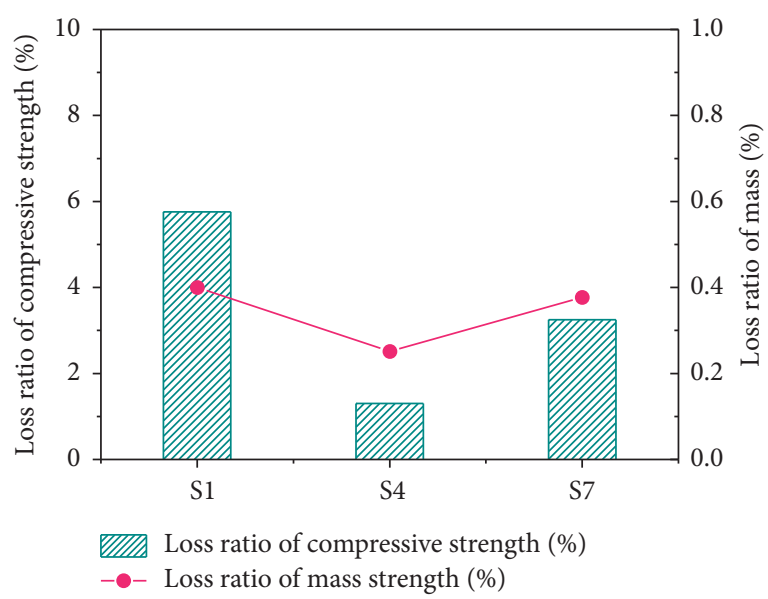

(a)

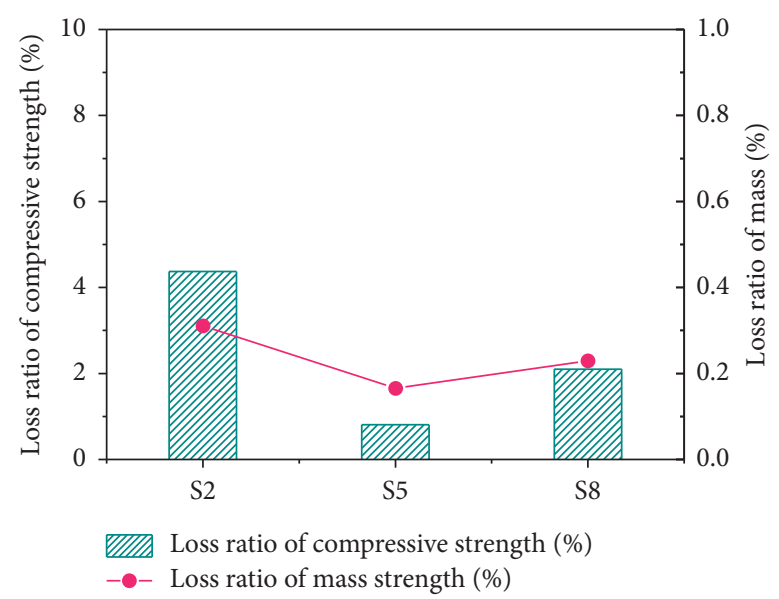

(b)

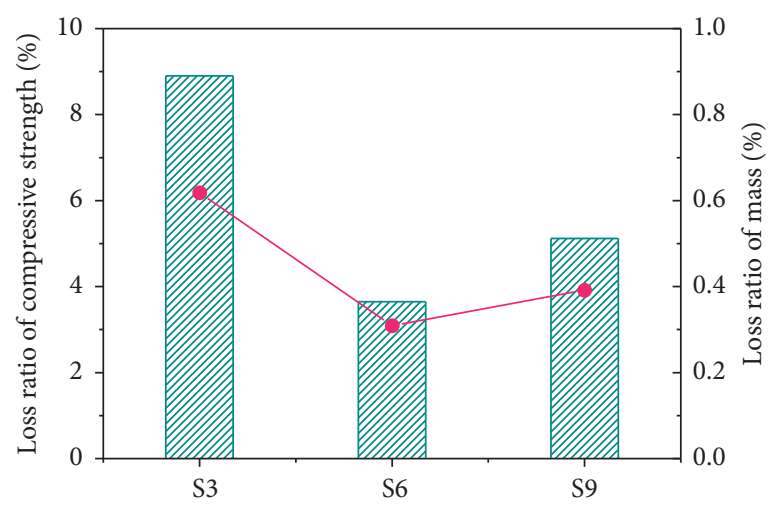

Loss ratio of compressive strength (\%)

- Loss ratio of mass strength (\%)

(c)

Figure 8: Compressive strength and mass loss rate of HPC different amounts of mineral admixtures. (a) $10 \%$, (b) $20 \%$, (c) $30 \%$.

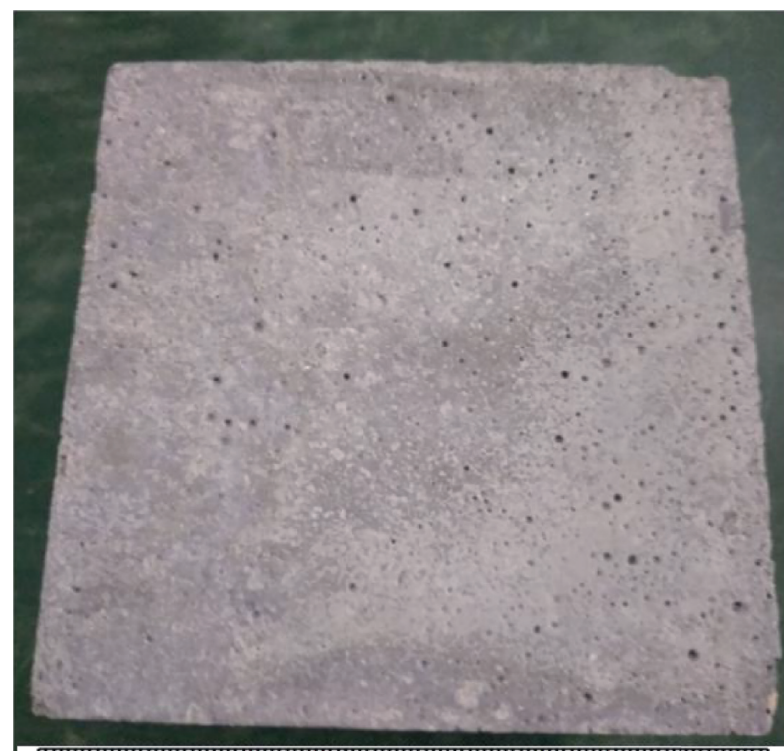

$0 \mathrm{~mm} 10 \mathrm{~mm} 20 \mathrm{~mm} 30 \mathrm{~mm} 40 \mathrm{~mm} 50 \mathrm{~mm} 60 \mathrm{~mm} 70 \mathrm{~mm} 80 \mathrm{~mm} 90 \mathrm{~mm} 100 \mathrm{~mm}$

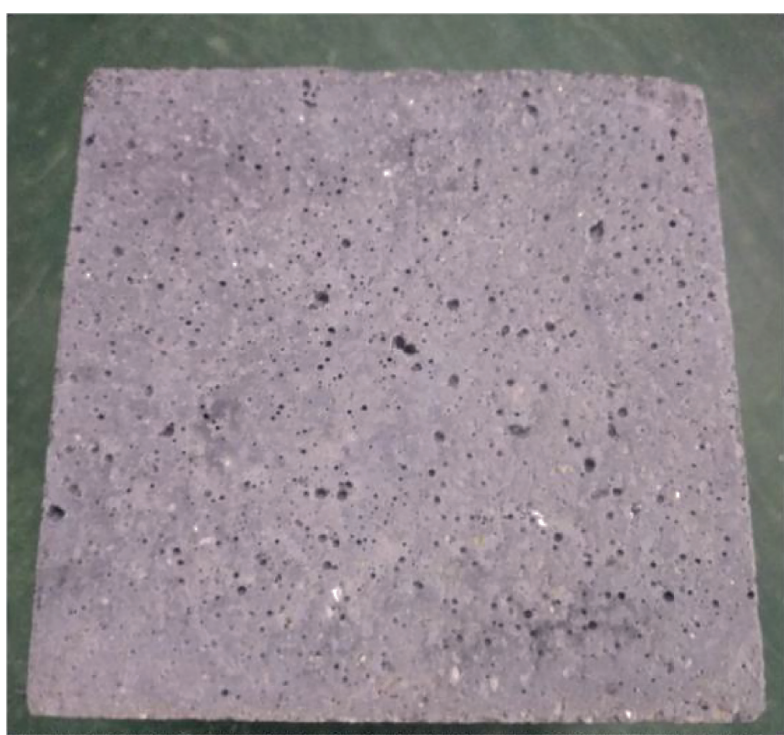

$0 \mathrm{~mm} 10 \mathrm{~mm} 20 \mathrm{~mm} 30 \mathrm{~mm} 40 \mathrm{~mm} 50 \mathrm{~mm} 60 \mathrm{~mm} 70 \mathrm{~mm} 80 \mathrm{~mm} 90 \mathrm{~mm} 100 \mathrm{~mm}$

(a)

(b)

Figure 9: HPC surface after 50 times freeze-thaw cycles. (a) Before; (b) after. 
Further, due to the relatively coarse and porous structure of CFBC ash and CFBC slag and the large number of internal pores, both played the role of air-entraining agents; thus, the frost resistance of the HPC was improved. However, when the CFBC ash and CFBC slag amount are too high, the proportion of cement decreases. Moreover, the amount of gel produced is reduced, the working performance of the HPC declines, and the internal compactness is insufficient. In the case of insufficient alkalinity in the later age, the internal components are easy to decompose; as a result, the pore structure changes and the frost resistance decreases.

Uysal et al. research shows that concrete mixed with fly ash can effectively improve the frost resistance of concrete $[44,45]$. As shown in Figure 8, the strength and mass loss rate of the HPC with fly ash were much higher than those of the other HPCs. It can be seen that, for all additive amounts, the HPC with CFBC ash had the best frost resistance compared with the other HPCs. Compared with the CFBC ash and CFBC slag, the early activity of fly ash was inadequate, and the expansion performances of CFBC ash and CFBC slag were mainly concentrated at the early age. A large number of expansion materials are formed, and they fill the internal pores of HPC, improving the pore structure and making the interior of HPC more compact and frost resistant. The physical appearances of HPC after 50 times freeze-thaw cycles are shown in Figure 9. After 50 times the freeze-thaw cycle, many pores appeared on the HPC surface, and the previously existing pores became larger, which was the main reason for the decrease in mass and strength.

\section{Conclusions}

(1) It is feasible to prepare high-performance concrete using fly ash, CFBC ash, and CFBC slag as mineral admixtures. The high-performance concretes can be prepared by mixing fly ash, CFBC ash, CFBC slag, and $9 \%$ silica fume with the amount of $10 \%, 20 \%$, and $30 \%$. The compressive strength can reach more than $60 \mathrm{MPa}$ at $28 \mathrm{~d}$ ages. After 50 times freeze-thaw cycles, the mass loss and strength loss are low, no more than $0.7 \%$ and $0.9 \%$.

(2) The varieties and amounts of mineral admixtures have obvious effects on the early compressive strength of high-performance concrete but have little effect in the later period of curing. The law of the fly ash and CFBC slag's amount on the HPCs' compressive strength is the same. While the amounts of the fly ash and CFBC slag increase, the HPCs' compressive strength decreases at each age. When the content of fly ash and CFBC slag is $10 \%$, the compressive strength reaches the maximum at each age. While the amount of CFBC ash increases, the compressive strength of the HPC first increases and then decreases at each age. When the amount is $20 \%$ of CFBC ash, the compressive strength reaches the maximum at each age.

(3) There are same laws for the frost resistance of HPCs with fly ash, CFBC ash, and CFBC slag. When the amount is $20 \%$, the frost resistance is the best. Among all three admixtures, HPC with CFBC ash has the best frost resistance.

\section{Data Availability}

The data used to support the findings of this study are included within the article and the supplementary information file.

\section{Conflicts of Interest}

The authors declare that they have no conflicts of interest.

\section{Acknowledgments}

This work was financially supported by the Science Fundamental Research Projects of Shanxi Province (nos. 201901D111169 and 201801D221233) and the Graduate Student Education Innovation Projects of Shanxi Province (no. 2020SY384).

\section{Supplementary Materials}

Figure S1: the images of CFBC ash, CFBC slag, and fly ash. Figure S2: the photos of freeze-thaw cycle test. Tables S1-S4: the data of the compressive strength of HPC. Tables S5-S7: the data of the compressive strength and mass loss of HPC after the freezing-thawing cycle in $28 \mathrm{~d}$ ages. (Supplementary Materials)

\section{References}

[1] X.-G. Li, Q.-B. Chen, K.-Z. Huang, B.-G. Ma, and B. Wu, "Cementitious properties and hydration mechanism of circulating fluidized bed combustion (CFBC) desulfurization ashes," Construction and Building Materials, vol. 36, pp. 182-187, 2012.

[2] N. Menad, J. N. Ayala, F. Garcia-Carcedo, E. Ruiz-Ayúcar, and A. Hernández, "Study of the presence of fluorine in the recycled fractions during carbothermal treatment of EAF dust," Waste Management, vol. 23, no. 6, pp. 483-491, 2003.

[3] E. J. Anthony, D. L. Granatstein, and C. Science, "Sulfation phenomena in fluidized bed combustion systems," Progress in Energy and Combustion Science, vol. 27, no. 2, pp. 215-236, 2001.

[4] J. Zhao, D. Wang, and S. Liao, "Effect of mechanical grinding on physical and chemical characteristics of circulating fluidized bed fly ash from coal gangue power plant," Construction and Building Materials, vol. 101, pp. 851-860, 2015.

[5] P. Grammelis, G. Skodras, E. Kakaras et al., "Effects of biomass co-firing with coal on ash properties part 2: leaching, toxicity and radiological behaviour," Fuel, vol. 85, no. 16, pp. 2316-2322, 2006.

[6] Y. Xia, Y. Yan, and Z. Hu, "Utilization of circulating fluidized bed fly ash in preparing non-autoclaved aerated concrete production," Construction and Building Materials, vol. 47, pp. 1461-1467, 2013.

[7] S. Duan, H. Liao, Z. Ma et al., "The relevance of ultrafine fly ash properties and mechanical properties in its fly ash-cement gelation blocks via static pressure forming," Construction and Building Materials, vol. 186, pp. 1064-1071, 2018. 
[8] Y. Shen, J. Qian, and Z. Zhang, "Investigations of anhydrite in cfbc fly ash as cement retarders," Construction and Building Materials, vol. 40, pp. 672-678, 2013.

[9] M. Chi and R. Huang, "Effect of circulating fluidized bed combustion ash on the properties of roller compacted concrete," Cement and Concrete Composites, vol. 45, pp. 148-156, 2014.

[10] J. Ding, S. Ma, S. Shen, Z. Xie, S. Zheng, and Y. Zhang, "Research and industrialization progress of recovering alumina from fly ash: a concise review," Waste Management, vol. 60, pp. 375-387, 2017.

[11] Z. Zhang, J. Qian, C. You, and C. Hu, "Use of circulating fluidized bed combustion fly ash and slag in autoclaved brick," Construction and Building Materials, vol. 35, pp. 109-116, 2012.

[12] L. Haibin and L. Zhenling, "Recycling utilization patterns of coal mining waste in China," Resources, Conservation and Recycling, vol. 54, no. 12, pp. 1331-1340, 2010.

[13] O. Font, P. Córdoba, C. Leiva et al., "Fate and abatement of mercury and other trace elements in a coal fluidised bed oxy combustion pilot plant,” Fuel, vol. 95, pp. 272-281, 2012.

[14] N. Selçuk, Y. Gogebakan, and Z. Gogebakan, "Partitioning behavior of trace elements during pilot-scale fluidized bed combustion of high ash content lignite," Journal of Hazardous Materials, vol. 137, no. 3, pp. 1698-1703, 2006.

[15] H. Xu, Q. Li, L. Shen et al., "Synthesis of thermostable geopolymer from circulating fluidized bed combustion (CFBC) bottom ashes," Journal of Hazardous Materials, vol. 175, no. 1-3, pp. 198-204, 2010.

[16] H. Xu, Q. Li, L. Shen, M. Zhang, and J. Zhai, "Low-reactive circulating fluidized bed combustion (cfbc) fly ashes as source material for geopolymer synthesis," Waste Management, vol. 30, no. 1, pp. 57-62, 2010.

[17] G. Skodras, P. Grammelis, M. Prokopidou, E. Kakaras, and G. Sakellaropoulos, "Chemical, leaching and toxicity characteristics of $\mathrm{cfb}$ combustion residues," Fuel, vol. 88, no. 7, pp. 1201-1209, 2009.

[18] J. Yuan, "The future of coal in China," Resources, Conservation and Recycling, vol. 129, pp. 290-292, 2018.

[19] I. Yurtdas, N. Burlion, J.-F. Shao, and A. Li, "Evolution of the mechanical behaviour of a high performance self-compacting concrete under drying," Cement and Concrete Composites, vol. 33, no. 3, pp. 380-388, 2011.

[20] A. H. Akca, N. Özyurt Zihnioğlu, and B. Materials, "High performance concrete under elevated temperatures," Construction and Building Materials, vol. 44, pp. 317-328, 2013.

[21] D. Harbec, A. Zidol, A. Tagnit-Hamou, and F. Gitzhofer, "Mechanical and durability properties of high performance glass fume concrete and mortars," Construction and Building Materials, vol. 134, pp. 142-156, 2017.

[22] B. Rabehi, Y. Ghernouti, K. Boumchedda, A. Li, and A. Drir, "Durability and thermal stability of ultra high-performance fibre-reinforced concrete (UHPFRC) incorporating calcined clay," European Journal of Environmental and Civil Engineering, vol. 21, no. 5, pp. 594-611, 2017.

[23] R. Siddique, "Utilization of silica fume in concrete: review of hardened properties," Resources, Conservation and Recycling, vol. 55, no. 11, pp. 923-932, 2011.

[24] E. Vejmelková, M. Pavlíková, M. Keppert et al., "High performance concrete with Czech metakaolin: experimental analysis of strength, toughness and durability characteristics," Construction and Building Materials, vol. 24, no. 8, pp. 1404-1411, 2010.
[25] R. B. Ardalan, A. Joshaghani, and R. D. Hooton, "Workability retention and compressive strength of self-compacting concrete incorporating pumice powder and silica fume," Construction and Building Materials, vol. 134, pp. 116-122, 2017.

[26] S. E. Chidiac, D. K. Panesar, and C. Composites, "Evolution of mechanical properties of concrete containing ground granulated blast furnace slag and effects on the scaling resistance test at 28 days," Cement and Concrete Composites, vol. 30, no. 2, pp. 63-71, 2008.

[27] S. Teng, V. Afroughsabet, and C. P. Ostertag, "Flexural behavior and durability properties of high performance hybridfiber-reinforced concrete," Construction and Building Materials, vol. 182, pp. 504-515, 2018.

[28] S. Rajaram, "Next generation CFBC," Chemical Engineering Science, vol. 54, no. 22, pp. 5565-5571, 1999.

[29] M. Abed and R. Nemes, "Long-term durability of self-compacting high-performance concrete produced with waste materials," Construction and Building Materials, vol. 212, pp. 350-361, 2019.

[30] X. Xu, Y. Xu, and L. Duan, "Effect of fineness and components of CFBC ash on performance of basic magnesium sulfate cement," Construction and Building Materials, vol. 170, pp. 801-811, 2018.

[31] H.-A. Nguyen, T.-P. Chang, and J.-Y. Shih, "Effects of sulfate rich solid waste activator on engineering properties and durability of modified high volume fly ash cement based SCC," Journal of Building Engineering, vol. 20, pp. 123-129, 2018.

[32] G. Sheng, Q. Li, and J. Zhai, "Investigation on the hydration of CFBC fly ash,” Fuel, vol. 98, pp. 61-66, 2012.

[33] G. Sheng, Q. Li, J. Zhai, and F. Li, "Self-cementitious properties of fly ashes from CFBC boilers co-firing coal and highsulphur petroleum coke," Cement and Concrete Research, vol. 37, no. 6, pp. 871-876, 2007.

[34] W.-T. Kuo, H.-Y. Wang, and C.-Y. Shu, "Engineering properties of cementless concrete produced from GGBFS and recycled desulfurization slag," Construction and Building Materials, vol. 63, pp. 189-196, 2014.

[35] Z. Cheng, Z. Cheng, H. Hou, T. Han, and L. Liu, "Research on the expansion characteristics and compressive strength of mortars containing circulating fluidized bed combustion desulfurization slag," Advances in Materials Science and Engineering, vol. 2018, Article ID 4150145, 11 pages, 2018.

[36] S. Bhanja, B. Sengupta, and C. Research, "Modified watercement ratio law for silica fume concretes," Cement and Concrete Research, vol. 33, no. 3, pp. 447-450, 2003.

[37] A. Behnood and H. Ziari, "Effects of silica fume addition and water to cement ratio on the properties of high-strength concrete after exposure to high temperatures," Cement and Concrete Composites, vol. 30, no. 2, pp. 106-112, 2008.

[38] R. Duval, E. H. Kadri, and C. Research, "Influence of silica fume on the workability and the compressive strength of highperformance concretes," Cement and Concrete Research, vol. 28, no. 4, pp. 533-547, 1998.

[39] S. K. Das, Y. J. Yudhbir, and C. Research, “A simplified model for prediction of pozzolanic characteristics of fly ash, based on chemical composition," Cement and Concrete Research, vol. 36, no. 10, pp. 1827-1832, 2006.

[40] R. Reis, R. Malheiro, A. Camões, and M. Ribeiro, "Carbonation resistance of high volume fly ash concrete," Key Engineering Materials, vol. 634, pp. 288-299, 2014.

[41] X. Fu, Q. Li, J. Zhai, G. Sheng, and F. Li, "The physicalchemical characterization of mechanically-treated CFBC fly 
ash," Cement and Concrete Composites, vol. 30, no. 3, pp. 220-226, 2008.

[42] X.-G. Li, Q.-B. Chen, B.-G. Ma, J. Huang, S.-W. Jian, and B. Wu, "Utilization of modified CFBC desulfurization ash as an admixture in blended cements: physico-mechanical and hydration characteristics," Fuel, vol. 102, pp. 674-680, 2012.

[43] W. Gu, F. Xu, S. Wang, W. Li, and Y. Tan, "Effect of fly ash content on the carbonization resistance of cement paste," IOP Conference Series: Earth and Environmental Science, vol. 153, 2018.

[44] M. Uysal, V. Akyuncu, and B. Materials, "Durability performance of concrete incorporating class $\mathrm{F}$ and class $\mathrm{C}$ fly ashes," Construction and Building Materials, vol. 34, pp. 170-178, 2012.

[45] C. Karakurt and Y. Bayazıt, "Freeze-thaw resistance of normal and high strength concretes produced with fly ash and silica fume," Advances in Materials Science and Engineering, vol. 2015, Article ID 830984, 2015. 